\title{
The Key Indicators of Probable Corruption Risks in Critical Areas of Military Activity (Ukrainian Experience)
}

\section{Olena Holota $^{\text {A }}$; Marina Barynina ${ }^{B}$; Oleksandr Tytkovskyi ${ }^{\mathrm{C}}$}

Received: April 4, 2020 | Revised: April 23, 2020 | Accepted: April 30, 2020

JEL Classification: Z3, M53, M54.

DOI: $10.33445 /$ sds.2020.10.2.8

\begin{abstract}
Using the approach of identifying 'red flags', the article analyses the most vulnerable areas of military activity such as defence procurement (acquisition); use of defence lands; housing provision for military personnel and their families; state defence enterprise activity; and use of fuel, to recognise the corruption risks and the consequences of improper activities in these areas for the Ministry of Defence and the Armed Forces.
\end{abstract}

Key words: 'red flags', corruption risks, internal control, internal audit, Armed Forces of Ukraine, Ministry of Defence of Ukraine.

\section{Introduction}

Due to the political situation of these days, one of the potential threats to the national security of Ukraine is slow progress in the reformation of the armed forces. Furthermore, given the level of corruption that prevails throughout the system of public administration, it should be noted that corruption is detrimental to all aspects of public life and is a major internal factor in undermining national security.

It should be emphasised that according to Transparency International's Corruption Perceptions Index 2019, the results for Ukraine are not encouraging - the country received only 30 points out of 100 , which is 2 points less than the previous year. According to the survey, Ukraine has returned to the level of 2017 and now ranks $126^{\text {th }}$ out of 180 countries. Countries such as Kyrgyzstan, Azerbaijan and Djibouti are close to the country. Among its neighbours,
Ukraine is ahead of Russia, which retained last year's positions and received 28 points, ranking 137th. [1] According to the latest Transparency International survey in the security and defence sector (Government Defence Anti-Corruption Index), Ukraine's security and defence sector ranked in the " $D$ " group (among A-F possible groups, where group $A$ includes the bestperforming countries, and group $\mathrm{F}$ includes the worst performing), which showed a low level of transparency and a high level of corruption risk in the sector [2].

In order to curb corruption in the security and defence sector, there is a need to recognise the probable corruption risks in the vulnerable areas of military activity. In the system of public administration, this ability is essential at every level in the control system.

\section{Material and methods}

The methodological basis of the article is the

complex of methods, including methods of

\footnotetext{
A The National Defence University of Ukraine named after Ivan Cherniakhovskyi, Kyiv, Ukraine, Candidate of Economic Sciences (PhD), Associate Professor, Doctoral candidate, e-mail: golota_I@ukr.net, ORCID: 0000-0003-4323-4344

${ }^{\text {B }}$ The Internal Audit Department of the Ministry of Defence of Ukraine, Kyiv, Ukraine, Director of the Internal Audit Department of the Ministry of Defence of Ukraine, Honoured Economist of Ukraine, Certified Auditor of Ukraine, Certified Professional Internal Auditor of Public Sector of Ukraine, e-mail: maryna.barynina@ukr.net, ORCID: 0000-0002-8820-3173

c The Territorial Administration of Internal Audit of Military Units directly subordinated to the Ministry of Defence and the General Staff of Armed Forces of Ukraine, Kyiv, Ukraine, Head of the Territorial Administration of Internal Audit of Military Units directly subordinated to the Ministry of Defence and the General Staff of Armed Forces of Ukraine, Certified Auditor of Ukraine, e-mail: tytkovskyi@ukr.net
} 
scientific cognition, analysis and synthesis, systematisation and scientific abstraction. The informational basis of the conducted research is scientific works of the domestic and foreign scientists in the sphere of risk management (including corruption risks), internal control and audit, and materials from internal audits of the Ministry of Defence of Ukraine. The purpose of this article is to analyse the most critical areas of military activity to identify 'red flags' that help to recognise possible corruption risks in these areas. 'Red flags' are useful tools that are widely used in internal control and auditing and help to identify and prevent corruption risks.

\section{Analysis of recent research and publications.} Research on various aspects of the corruption risks in the defence and security sector include dedicated works by authors such as A. Balanda, M. Barynina, Z. Varnaly, A. Voloshenko, M. Holomsha, O. Holota, T. Kovalchuk, O. Kotliarenko, E. Nevmerzhytsky, M. Pyman, L. Poliakov, S. Rose-Ackerman and others. However, in the field of scientific research of the corruption risk in the security and defence sector of Ukraine, no comprehensive research using the 3E approach and 'red flags' has been undertaken.

\section{Results and discussion}

In the face of armed conflict in the eastern part of Ukraine, the main strategic-level risks to the Ministry of Defence (hereafter MoD) and the Armed Forces (hereafter AF) are risks of the loss of lives, loss of financial resources, and loss of reputation. Therefore, these risks formed the basis of the study. It is noteworthy that the study does not address other non-corruption related causes (actions and events that create risks) such as lack of competence or experience, imperfect legislation or procedures, poor governance, etc. However, all of the risks identified in the survey, their causes and impact, do not necessarily indicate actual corruption, but only indicate its likelihood.

It should be pointed out that in the modern world, the optimal allocation of scarce resources among abundant competing alternatives to maximise national security over time is a fundamental challenge for defence resources management.

This allocation of resources is impossible in practice without applying three basic principles of good governance: economy, efficiency and effectiveness.

Economy covers the financial side by which an activity is achieved. Because we are living in a world in which economics permeates every aspect of our lives, it is fundamental to the balance of using resources to meet the right goals at a reasonable cost.

Efficiency, on the other hand, involves the right use of resources to accomplish a task. It means the wise consumption of inputs on which the work is completed. Once the goals are attained, it is essential to see how they can be met with the least effort [3].

Effectiveness is the degree to which objectives are achieved and the extent to which targeted problems are solved. In contrast to efficiency, effectiveness is determined without reference to costs and, whereas efficiency means "doing the thing right," effectiveness means "doing the right thing" [4].

Nowadays, Ministries of Defence are concerned with effectiveness, to produce the best possible defence forces to satisfy both national and collective security demands, and efficiency, to ensure the best use of limited budget [5].

It should be borne in mind that the main obstacles to the achievement of strategic and operational objectives in security and defence, as well as the objectives of compliance and reporting, are fraud, inefficient managerial decisions, illegal actions and other kinds of improper activity that lead to loss of resources, failure to achieve goals and ineffective results of activity, etc.

Moreover, we need to keep in mind that these activities may be caused by corruption, which is defined as the abuse of entrusted power for private gain. A characteristic feature of corruption is a conflict between the activities of an official and the interests of the body (authority) on whose behalf he/she acts. Many 
kinds of corruption are similar to fraud carried out by an official, and belong to the category of 'crimes against state (municipal) property.'

This activity brings extremely negative consequences for the country's defence. Corruption undermines the proper functioning of military bodies by eroding their credibility, legitimacy, and accountability. Such structural units that become paralysed by corruption are unable to perform their necessary activity properly, are unable to maintain the rule of law, and, as a consequence, fail to maintain a safe and secure environment for citizens.

Furthermore, corrupt activities have an extremely negative impact on operational effectiveness: reducing interoperability, combat capability and purchasing power of military budget, reducing public trust in the armed forces, facilitating organised crime and undermining faith among the international community [6; 7].

According to the last published Government Defence Anti-Corruption Index by Transparency International, despite significant progress, Ukraine is in a group with high risk of corruption. The recommendations of international experts are unambiguous - anti-corruption efforts should be doubled.

In two areas, there was definite progress, namely: the activities of the Building Integrity
Training Education Centre of National University of Defence of Ukraine and in the MoD's internal audit [2].

The contribution of internal audit should be mainly seen in the context of building integrity, encouraging an anti-corruption culture, and sustaining an environment of 'zero tolerance' to corruption. Following applicable law and generally accepted international standards, the internal audit activity is mainly focused on the analysis and assessment of the effectiveness and efficiency of the internal control system and risk management.

During the execution of their direct functional duties, internal auditors mainly deal with the violation of the law, inefficient use of public resources and assets, failure to comply with procedures, neglect of duties, poor management practices etc.

However, the internal auditor should (Fig. 1):

consider the possibility that corruption could be present in each of these kinds of activity;

evaluate anti-corruption strategies (programs);

recognise signs that may indicate corruption or abuse of power during the control measures, and (if necessary) conduct an appropriate audit; provide recommendations to prevent corrupt practices.
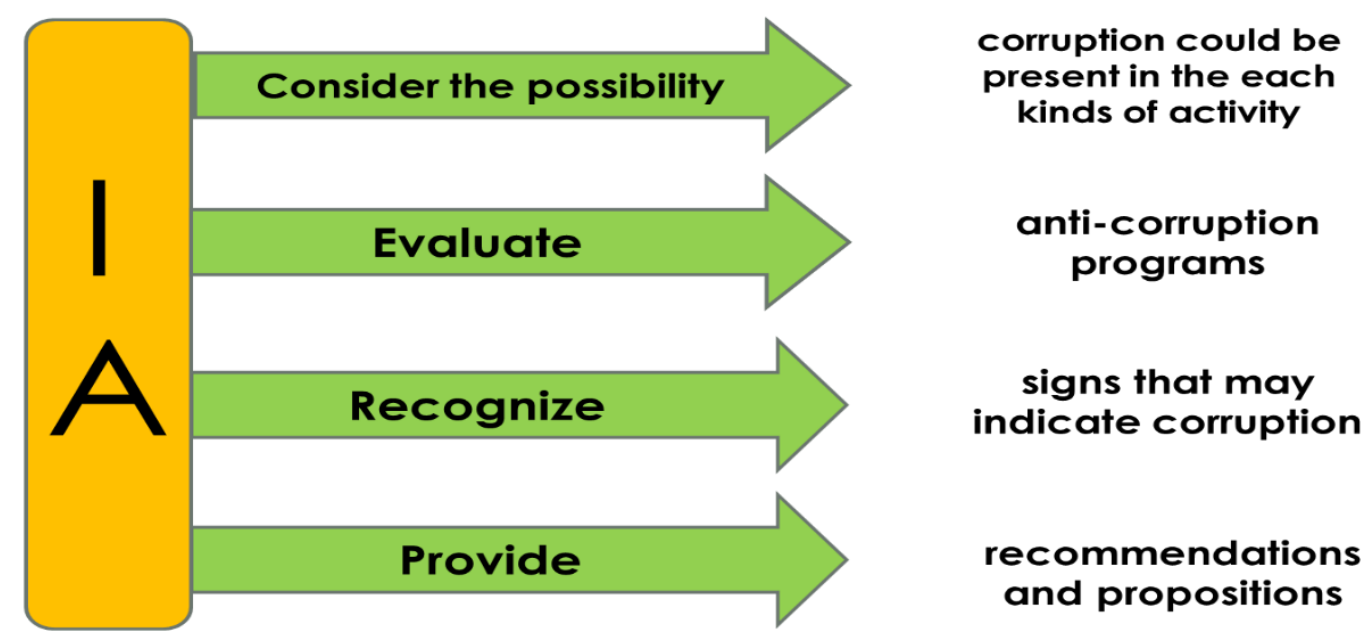

Fig. 1 Set of essential practical skills for an internal auditor

Besides this, public sector internal auditors must immediately inform the head of the central executive body (its territorial authority and public institutions) about the signs of fraud, corruption or misuse of budgetary funds, abuse of power and other violations of financial and fiscal discipline 
that led to losses. They must also recommend necessary measures concerning: the functioning of the internal control system and its improvement; improving governance; prevention of facts of illegal, inefficient and non-effective use of funds; prevention of errors or other deficiencies [8].

Based on the practice of internal auditing, we can identify the following five main areas of military activity, which are the most vulnerable to violations with signs of possible corruption: defence procurement (acquisition); use of defence lands; provision of housing for military personnel and their families; state defence enterprise activity; and fuel consumption.

According to the results of the analysis of the current practice of internal audit, we can identify the principal risks, possible components of corruption and the consequences of improper activities in each of the above areas of activity.

It should be noted that the primary purpose of this research is to show the fundamental indicators (so-called 'red flags', which point the internal auditor to the possibility of the existence of violations with signs of corruption).

Defence procurement (acquisition) of goods, works, and services (hereafter GWS)

The main risks for defence (acquisition) procurement of GWS are indicated as: loss of lives through the procurement of military weapons, technical equipment, and personnel protective equipment (including body armour vests) of poor quality; harming the health of military personnel through poor quality of nutrition, military uniforms and gear; the lack of funds for supplying the $A F$, either as a result of spending on urgent needs or through procurement of GWS at unreasonably inflated prices; undermining confidence in the MoD and the $A F$ through corruption scandals.

Possible components of corruption include collusion between officials (who are responsible for the procurement of GWS) and the suppliers (or intermediaries) to receive an unlawful benefit (kickbacks, bribes, expensive gifts, services, etc.) through supplying poor quality GWS for the military and/or at inflated prices.

The main consequences are reducing combat effectiveness and capabilities to respond adequately and promptly to military threats, up to and including loss of lives and territories; diminished capacity or inability to finance essential needs of the AF; decreased motivation for military service, increased tension in the military teams; reputation losses at both local and international levels.

The likelihood a component of corruption may indicate the following 'red flags', such as unreasonable 'secrecy' or unsupportable 'short term' of procurement deadlines due to urgent needs, which must, in fact, be governed by general rules; the insufficient choice of uncompetitive procedures and other methods of restricting competition, for example, the unjustified allocation of procurement into small amounts (below thresholds) to avoid more transparent tendering procedures; signs of unreasonably narrow contract specifications that favour a particular bidder winning and which exclude others; unreasonable prequalification methods that exclude qualified bidders, or which allow unqualified bidders to compete; avoidance of competitive procedures through the artificial application of the procurement procedure for urgent needs; disqualification of bidders for arbitrary or trivial reasons during bid evaluation; unjustified avoidance of established procedures for acceptance of purchased GWS for their compliance with quality indicators, complaints about the quality of purchased GWS, and/or lack of guarantees [9]; prolonged non-use of purchased GWS (which are not actually needed for the MoD and the AF) due to their unjustified inclusion in the procurement plan, or purchases of GWS offered by suppliers instead what is required by the MoD and the AF; inflating prices through the use of intermediaries and/or subcontractors; entering into agreements with disreputable suppliers (who have previously supplied products to the MoD and the AF and are known for failing to fulfil their obligations in a timely or poor manner); negative or critical media publications.

\section{Use of defence lands}

The main risks for the area of inappropriate use of defence lands are indicated as loss of assets due to unjustified changes in the designated purpose of defence lands; loss of funds through undue alienation of defence lands or misuse of them by 
entities other than the AF and individuals; lack of funds needed for (provisioning) supplying of the $A F$ as a result of the improper using of defence lands and forests (not for the interests of the AF); undermining confidence in the MoD and the $A F$ through corruption scandals.

Possible components of corruption include collusion between officials (responsible for the accounting and use of defence lands and forests) and commercial entities and individuals for undue benefits (kickbacks, bribes, expensive gifts, services, etc.) through the unjustified granting of permits for the alienation or commercial use of defence lands and forests.

The main consequences are the loss of lives and the inadequate level of security of civilians and civilian infrastructure due to a lack of sufficient defence land around storage depots, bases, arsenals and other military facilities; reducing combat effectiveness because of training restrictions due to a lack of sufficient defence land around firing ranges and training centres; unforeseen costs of emergency response; loss of income from the commercial use of land and defence forests by non-AF entities and individuals; increasing the expense of acquiring products for the AF that could be made from wood (timber) growing on defence lands; deteriorating of staff morale in military teams; reputation losses at both local and international levels.

The likelihood of a component of corruption may indicate the following 'red flags', such as increasing of number of defence lands and areas; violation of rules and procedures in granting permits to non-AF entities and individuals to alienate or use the land; lack of legal documents for land plots; improper accounting of defence lands; discrepancy in land accounting by the MoD and the data of state land registers; use of defence lands by commercial entities and individuals without proper grounds (including encroachment of land); unreasonably low revenues from the use of defence lands under awarded contracts, loss of forest management structures; unreasonably high prices for timber and timber products supplied by the AF; negative or critical media publications.

Provision of housing for military personnel and their families

The main risks in provision of housing are indicated as additional costs due to providing housing for personnel who have not acquired (or lost) the right to receive it; unnecessary expenditure as a resulting of housing procurement at inflated prices or exceeding statutory criteria; increased costs due to the overestimation of construction costs, unreasonably long construction time, and contractors failing to comply with their agreed obligations; undermining confidence in the MoD and the AF through corruption scandals.

Possible components of corruption include a lack of integrity in the personnel responsible for registration and allocation of housing; collusion between suppliers and staff accountable for housing construction and procurement.

The main consequences included: reduced combat effectiveness due to understrength military units because of lack of prestige of military service and a 'weak' social package; loss of defence budget, failure to provide social guarantees for military personnel; lack of resources for essential needs of the AF; deteriorating staff morale in military teams; reputation losses at both local and international levels.

The likelihood of a component of corruption may indicate the following 'red flags', such as unreasonable registration of military personnel who have not acquired (or lost) the right to receive housing; absence (full or partial) of documents required for registration and/or allocation of housing, as well as their loss or premature destruction; unjustified violation of priority in the housing distribution; excessive housing cost or space in comparison to established standards; an increase in the price of construction compared to the original estimate, non-compliance with construction terms, other violations by contractors, non-application of penalties for breach of contract; negative or critical media publications.

\section{State defence enterprise activity}

The main risks in the area of state defence enterprise activity include a failure by the MoD state-owned enterprises of their statutory activities in the interests of the MoD and the AF; fictitious business activities, contracts award, not in the benefits of the MoD, unjustified alienation 
and decommissioning of property; artificial bankruptcy for disposal of assets of the enterprise at unreasonably low prices; undermining confidence in the MoD and the $A F$ through corruption scandals.

Possible components of corruption include a lack of integrity of heads of state-owned enterprises, as well as their collusion with buyers and suppliers.

The main consequences are reduced combat effectiveness and/or extra costs due to nondelivery of GWS to the AF by the MoD stateowned enterprises; loss of the MoD state-owned enterprises assets (movable and immovable assets, means as a result of their bankruptcy; loss of income as a result of underpricing of GWS sold by the MoD state-owned enterprises to third parties; incremental costs due to the overestimation of prices for GWS procured by the MoD state-owned enterprises; deteriorating staff morale in military teams; reputation losses at both local and international levels.

The likelihood of a component of corruption may indicate the following 'red flags', such as nonapproval and/or nondelivery of business plans; lack of or inaccurate accounting, failure of reporting; absence or premature destruction of accounting documents; baseless award of storage contracts instead of lease contracts; unjustified writing-off receivables; increasing payables, including payment of salaries, payments into the budget; spending not only on non-urgent needs in the presence of payables, selling of GWS at prices below the average market price and/or below the prime cost; procurement of unnecessary GWS or at inflated prices; unjustified write-off of movable and immovable assets; negative or critical media publications.

\section{Fuel consumption}

The principal risks of fuel consumption include a lack of fuel to carry out the AF tasks through theft; extra (unnecessary) expenditures on the procurement and transportation of fuel, as well as lack of funds for other essential needs of the AF; undermining confidence in the MoD and the $A F$ through corruption scandals.

Possible components of corruption include collusion between individuals responsible for material valuables and individuals who sign or approve the fact of using (writing off) fuel to sell it.

The main consequences are reduced combat effectiveness and capabilities to respond adequately and promptly to military threats, up to and including loss of lives and territories; diminished ability or inability to provide funding of essential needs of the AF; decrease in motivation for military service, deteriorating staff morale in military teams; reputation losses at both local and international levels.

The likelihood of a component of corruption may indicate the following 'red flags', such as improper accounting of fuel operations (capitalisation (posting), movement, use, writeoff); not accounting or incomplete capitalisation (posting) of fuel; premature destruction of documents on the use of fuel (in particular travel letters); loss of documents (check requirements, invoices, power of attorney); unreasonable increase in the volume of used fuel compared to previous periods or comparison with similar military units; fuel write-off for defective equipment or repair; application in writing off excess rates or unreasonable coefficients; failure to conduct or improperly conduct inventory and checks; unjustified transfer of fuel between military units without the decision of the security authority; misstatement of the route towards its increase or even a fictitious registration of traffic, which allows to write off and assign fuel without reason; negative or critical media publications.

If internal auditors recognise such signs of activity that may be associated with corruption during the execution of their direct duties, they must take all necessary measures to: identify all corresponding risks; assess them for likelihood/probability and their impact on results of military activity; make proposals and recommendations on appropriate steps for managing these risks to reduce their harmful effect.

The ability of the internal auditor to correctly identify and assess the risks and to formulate clear recommendations to reduce them is one of the most critical factors in the success of the internal audit engagement.

That, in turn, contributes to compliance with the principles of effectiveness, efficiency, and economy in the allocation of military resources to 
achieve the main goal of the MoD and the AF, namely to ensure the country's defence and border integrity.

At the same time, it should be emphasised that it is not internal auditors, but managers (the socalled process owners) who are responsible for achieving the set goals, and in the best way (while respecting the principles of economy, efficiency and effectiveness). Executives are accountable for implementing internal audit recommendations and reducing the risk of corruption.

\section{Conclusions}

In the article we identified:

the most vulnerable areas of military activity as defence procurement (acquisition); using of defence lands; providing housing for military personnel and their families; state defence enterprise activity; and fuel consumption; that using the 'red flags' approach can help managers to find possible corruption risks in a military activity that could be highly useful for preventing such threats in future.

\section{References}

1. Analiz rezul'tativ Indeksu spryjniattia koruptsii-2019 [Analysis of the Corruption Perceptions Index 2019]. Retrieved from http://cpi.ti-ukraine.org/\#/ [in Ukrainian].

2. Government Defence Anti-Corruption Index. Retrieved from http://government. defenceindex.org/countries/ukraine/.

3. Audit Advisory Training. Retrieved from http://www.en.valuemex.com/node/23.

4. Effectiveness. Retrieved from http://www.businessdictionary.com/defini tion/effectiveness.html

5. Todor Tagarev, ed., (2010). Building integrity and reducing corruption in defence: $a$ compendium of best practices. Geneva: DCAF. Retrieved from https://www.nato.int /nato_static_fl2014/assets/pdf/pdf_topics/ 20120607_BI_Compendium_EN.pdf

6. Corruption \& Peacekeeping. Strengthening Peacekeeping and the United Nations. (2016). Retrieved from https://ti- defence.org/wp-content/uploads/2016/ 03/2013-10_-Corruption-PK-report.pdf

7. Corruption Threats \& International Missions. Practical Guidance for Leaders. (2016). Retrieved from http://ti-defence.org/wpcontent/uploads/2016/03/140930-Corrup tion-Threats-International-Missions.pdf.

8. Barynina, M., \& Pyman, M. (2016). The 3rd line of defence: how an audit can help address defence corruption. The experience of Ukraine. Retrieved from https://tidefence.org/wp-content/uploads/2016/03 /2012-03_3rdLine_AuditsDefenceCorrup tion.pdf.

9. Holota, O. (2018). Public procurement as one of the biggest vulnerable direction to corruption of the ministry of defense. Journal of Scientific Papers "Social Development and Security», 4(2), 14-27. https://doi.org/10.5281/zenodo.1229619 [in Ukrainian]. 